\title{
Folic Acid Measurement
}

National Cancer Institute

\section{Source}

National Cancer Institute. Folic Acid Measurement. NCI Thesaurus. Code C74676.

The determination of the amount of folic acid present in a sample. 